\title{
A NEGAÇÃO DO DIREITO À EDUCAÇÃO DEMOCRÁTICA DIANTE DAS INVERDADES DO ESCOLA SEM PARTIDO
}

DOI: 10.48075/RI.V22I2.25388

Victor Pereira de Sousa ${ }^{1}$

RESUMO: A busca por uma educação que seja verdadeiramente democrática, e que apresente características libertárias e emancipatórias, é rodeada de obstáculos que precisam ser superados. Retrocessos e descaminhos se encontram nas fronteiras da consolidação do direito à educação. Assim, por meio de sólida pesquisa bibliográfica, o presente artigo tem como objetivo desmistificar o Escola Sem Partido em relação às suas especificidades que propõem uma educação neutra e apolítica. Ainda, busca-se refletir sobre o conceito democrático da educação em patamares de justiça social e igualdade de direitos, pensando na educação como ferramenta principal de mobilidade social.

Palavras-chave: Educação; Escola Sem Partido; Democracia.

\section{CULTURE AND HYBRIDISM: PSYCHOSOCIAL ASPECTS OF CONTEMPORARY CULTURAL IDENTITY}

ABSTRACT: The search for an education that is truly democratic, and that has libertarian and emancipatory characteristics, is surrounded by obstacles that need to be overcome. Regressions and deviations are found at the borders of the consolidation of the right to education. Thus, through solid bibliographic research, this article aims to demystify Escola Sem Partido in relation to its specificities that propose a neutral and apolitical education. Still, it seeks to reflect on the democratic concept of education in terms of social justice and equal rights, thinking of education as the main tool of social mobility.

Key words: Education; Escola Sem Partido; Democracy.

\footnotetext{
${ }^{1}$ Mestrando em Geografia (UFRRJ), Especialista em Antropologia (UCAM), especialista em Filosofia e Direitos Humanos (UCAM), Licenciado em Geografia (UERJ), Licenciado em Ciências Sociais (UNICSUL), graduando em Pedagogia (UNIRIO). Nova Iguaçu - Rio de Janeiro. victordesousa@outlook.com.br
} 


\title{
INTRODUÇÃO
}

\author{
Mil nações \\ Moldaram minha cara \\ Minha voz \\ Uso pra dizer \\ O que se cala \\ Ser feliz, ser triste \\ É força que me embala \\ O meu país \\ É meu lugar de fala
}

(Elza Soares, "O Que Se Cala")

Esse é um texto que fala de resistência. Trata-se de reflexões acerca da resistência da educação como direito, de um ensino que seja livre e autônomo. Por uma educação de qualidade que busque a autonomia em uma condição democrática de um Estado que se diz democrático de direito.

Devemos, então, considerar que tivemos avanços na educação brasileira ao longo do tempo, principalmente por causa de movimentos sociais, como o Escola Nova, de políticas públicas voltadas para a área educacional, assim como a regulamentação da Lei de Diretrizes e Bases da Educação Brasileira (LDB 9394/96), mas que não devemos cair na ilusão de compreender que foi suficiente, uma vez que, muito ainda precisa ser feito. Não satisfatório, encontramos pelo caminho, desvios e retrocessos que nos fazem repensar nossa resistência construída e reconstruída no espaço-tempo.

O texto também trata de denúncias ao retrocesso maquiado de uma "nova" concepção de modelo educacional, como é o caso do projeto de lei no 193/2016, de autoria de Magno Pereira Malta, do Partido da República, apresentado em 2016, que buscou incluir entre as diretrizes e bases da educação brasileira o Escola Sem Partido, fundamentado em discursos um tanto quanto reducionistas ${ }^{2}$ que propalam o ódio e negam tanto o direito à educação

\footnotetext{
${ }^{2}$ Utilizando-se das ideias de Penna (2017), Maria Ciavatta esclarece tal questão ao nos conduzir que o Escola sem Partido utiliza-se de uma "linguagem próxima do senso comum, recorrendo a dicotomias simplistas que reduzem questões complexas a falsas alternativas", e expande-se por meio de memes, "imagens acompanhadas de breves dizeres", por "quatro elementos principais: primeiro, uma concepção de escolarização; segundo, uma desqualificação do professor; terceiro, estratégias discursivas fascistas; e, por último, a defesa do poder total dos pais sobre os seus filhos". Contém estratégias discursivas fascistas através de "analogias voltadas à docência, que desumanizam o professor", tratando-o como "um monstro, um parasita, um vampiro" na forma de memes Ideação. Revista do Centro de Educação, Letras e Saúde. v. 22, n¹, 2020. e-ISSN: 1982-3010.
} 
quanto a democracia - ainda em construção - no Brasil, dissimuladamente propostos pelo projeto. Demonstrando aversão à diferença e à diversidade. Por isso, antirrevolucionário e antidemocrático.

Para uma pedagogia autônoma e democrática, devemos, em primeiro lugar, repensarmos a educação quanto porta para a liberdade, levando em consideração que "educar é sempre partir do que se tem para chegar ao que se quer" (BALESTRERI, 2010, p. 112). Nesse patamar, não podemos compreender a educação como algo a parte das posturas e posição políticas - políticas, não partidárias -, assim como, não podemos vê-la como um fragmento alheio à realidade.

Esses breves esclarecimentos são necessários para que iniciemos as reflexões e discussões propostas por esse texto. Trata-se de um recorte de análise necessário para que possamos então situarmos as problemáticas em questão. Pensando em diálogos democráticos, seguiremos em aspectos que busquem na educação olhares críticos diante da realidade atual na qual vivemos, e nos tempos sombrios que nos esperam mais a frente. $\hat{E}$ necessário ressaltar ainda, que não ficaremos presos a tautologias e sim, usaremos de discursos talvez já sabidos por muitos, mas buscando vê-los de outro ângulo, para alcançarmos as questões pertinentes ao tema.

Assim, por meio de sólida pesquisa bibliográfica, como os contributos de Freire (2017a; 2017b; 2017c) e de Alves (2002; 2003) sobre educação, de Carvalho (2018), Orlandi (2017) e Viola (2010) sobre as concepções de igualdades de direito e de educação democrática, além de documentos oficiais como o Projeto de Lei 193/2016 do Escola Sem Partido, a Constituição Federal de 1988 e a Lei de Diretrizes e Bases da Educação Nacional no 9394/96; o presente artigo tem por objetivos a reflexão crítica sobre o papel da educação enquanto autônoma e democrática diante do contexto da consolidação da cidadania nos patamares da educação como um direito, além de proporcionar caminhos que aguçam o senso crítico diante das propostas do projeto de lei do Escola Sem Partido enquanto projeto de deseducação do povo para manutenção de poder, com projeções de uma educação neutra e de regresso educacional diante das (re)configurações do pensamento crítico e democrático.

Sem quórum, o presidente da comissão especial do Escola Sem Partido, deputado Márcio Rogério (DEM-RO) encerrou no dia 11 de dezembro de 2018 o trabalho da comissão

ofensivos, incluindo Gramsci e Paulo Freire. Instalam um "clima de denuncismo" e "um discurso de ódio". (2017, p. 10, grifos da autora). 
sem conseguir votar para o projeto lei e, com isso, o mesmo foi arquivado, mas nada o impede de retornar à pauta em uma próxima legislatura.

Como parte da estratégia política, é possível que o projeto tenha sido arquivado propositalmente, pois, pela falta de quórum o projeto não seria aprovado e antes que não passasse para aprovação o projeto foi retirado de pauta para que modificações possam ser feitas no texto do projeto de lei podendo assim vencer a oposição e conseguir a aprovação em uma próxima legislatura. Assim, caso haja um futuro desarquivamento, a tramitação do projeto deverá começar do zero, seguindo o regimento da casa pelas permissões permanentes ou, ainda, criando comissão especial, como estava ocorrendo no processo.

Por isso, e por todo o debate levantado com as propostas desse projeto de lei, é que não podemos deixá-lo de lado, correndo o risco de ser elevado mais uma vez a pauta de discussão, podendo ser aprovado futuramente.

\section{O MITO DO ESCOLA SEM PARTIDO E SUAS PROPOSTAS ANTIDEMOCRÁTICAS ${ }^{3}$}

É muito comum ainda hoje encontrarmos diversos discursos onde há confusão clara entre política e partido. O próprio nome do Escola Sem Partido ${ }^{4}$, deixa clara a ideia da sustentação desse equívoco que ganhou muita força em diferentes camadas e classes sociais com o mito de que as escolas brasileiras estão sofrendo doutrinação ideológica partidária.

Desse modo, o desentendimento desses conceitos - política e partido - acaba solidificando na sociedade a ideia de doutrinação realizada dentro das escolas. Presenciamos um momento em que as redes sociais se tornaram instrumento de informações que não mais - se um dia já foram - checadas, compartilhadas por uma gama de indivíduos que não tem o menor conhecimento no assunto, mas que tem a retórica exata para dizer/escrever tudo aquilo que ele sabe que as pessoas querem ou precisam ouvir/ler.

Nesse patamar, para Carvalho (2018, p. 68) o objetivo do Escola Sem Partido é "controlar o trabalho dos professores, na expectativa de fragilizar sua ação política, visando,

\footnotetext{
${ }^{3}$ Todas as afirmações e discussões levantadas nesse texto tem base nas propostas elaboradas pelo Escola Sem Partido e que estão disponíveis no site https://www.programaescolasempartido.org/. As consultas foram realizadas entre 16 de dezembro de 2018 e 13 de janeiro de 2019.

${ }^{4} \mathrm{O}$ argumento veiculado é o de que a escola pública estatal, no Brasil, foi tomada pelos partidos de esquerda, que a utilizam como meio de transmissão de suas ideias. Assim, as escolas, tornaram-se a escola de um partido, o partido de esquerda (CARVALHO, 2018, p. 81).
} 
também, interferir no debate acerca da necessidade de controlar os espaços públicos". Nesse viés:

\begin{abstract}
Entendemos que a historicização dos processos sociais é fundamental, pois viabiliza a compreensão da constituição dos mecanismos de produção e reprodução da vida em todo o seu dinamismo. Dessa forma, as relações sociais não podem ser apreendidas tão somente como engrenagem de um processo que apresenta sua origem, constituição e maturação tampouco como um dado preestabelecido, descolado dos interesses dos atores individuais e coletivos que constituem a razão de ser do ser social (CARVALHO, 2018, p. 69).
\end{abstract}

Ora, é a escola por excelência um espaço privilegiado onde o ser social se reconstrói diariamente, onde há a convivência direta entre a educação e a sociedade, fazendo dela um instrumento próprio de mobilidade social. Para a escola que preza por uma educação autônoma, libertadora e democrática, é imprescindível que os processos sociais sejam pauta de discussão, diálogo e (auto)crítica, uma vez que enquanto constituinte e constituída do ser social, a escola em si necessita ser para todos e todas um espaço de comprometimento com a cidadania, fazendo jus a democracia na qual o Brasil se ilustra em processo.

É possível compreendermos então que o Escola Sem Partido nega o próprio direito à educação enquanto direito social de reformulação constante do ser social, demarcado pelos efeitos e acontecimentos de sua época.

Aspecto central do discurso do ESP, e que tem demarcado sua atuação e inserção, no diabete curricular, é a tese que defendem acerca da necessidade de a legislação definir a fronteira entre o que eles entendem por formação e escolarização. Tese controversa, em que o papel da família e da escola seria estabelecido visando permitir que as famílias definissem o que é melhor para seus filhos no campo da formação, e a escola cuidasse da escolarização. Argumentam que a formação cabe à família, pois trata de questões religiosas, de sexualidade, de análise política, de família e da moral em geral, questões que não caberiam à escola interferir. Com isso, a escolarização deveria se ater à transmissão do conhecimento, que ficaria restrito a fatos naturais e históricos, mas tratados sem a interferência do professor. Os professores devem propiciar aos alunos o acesso ao conhecimento, mas não devem emitir opiniões, seja ela qual for. Para justificar seu discurso, apresentam exemplos de como os professores interferem e influenciam na formação dos alunos, em campos que consideram exclusivos da família: a formação política e a discussão sobre sexualidade (CARVALHO, 2018, p. 79).

Desse modo, é possível compreender que o Escola Sem Partido não mantém seu foco de preconização em aspectos de fundamental relevância para a melhoria da qualidade da educação brasileira, como afirma o projeto de lei, pois, ao pensarmos em problemáticas que 
envolvem a qualificação dos e das profissionais, a infraestrutura dos prédios escolares, a remuneração dos professores e das professoras, a dificuldade encontrada pelos alunos e alunas no domínio de conhecimentos básicos, as condições de vida nas quais os e as estudantes encontram-se submetidos fora das escolas, a falta de instrumentos mínimos de trabalho docente, a qualidade dos livros trabalhados pelas escolas, a falta de merenda escolar, e muitos outros, não encontram-se discutidos nas propostas do referido projeto lei.

A legitimação do Escola Sem Partido busca, explicitamente em suas propostas, a perseguição de professores e professoras, principalmente das áreas competentes as ciências humanas e sociais, que são acusados e acusadas de doutrinadores e doutrinadoras, pois, como aponta o texto de justificativa do projeto de lei no 193/2016 que diz ser "necessário e urgente adotar medidas eficazes para prevenir a prática da doutrinação política e ideológica nas escolas, e a usurpação do direito dos pais a que seus filhos recebam a educação moral que esteja de acordo com suas próprias conviç̧ões" (BRASIL, 2016, p. 4).

A educação como um direito social, e como caminhos autônomo e democrático, vai em contramão ao que o Escola Sem Partido almeja para a formação escolar, suposta e covardemente, reforçada por um discurso de proteção da família, da moral e dos bons costumes, pois:

Conforme se pode observar, o controle e a criminalização da ação docente se conjugam com uma exortação para que os pais e alunos ajam de forma policialesca, denunciando os docentes que agirem de modo que considerem inadequado. E por inadequado entenda-se que apresentem a seus filhos conteúdos com os quais estejam em desacordo (SARAIVA \& VARGAS, 2017, p. 72).

Na perspectiva do projeto, uma sociedade autônoma e verdadeiramente democrática simboliza, primeiramente, perigo as suas ambições de poder e dominação nas mais diversas esferas e escalas sociais, tendo, então, a necessidade de projetar em nossas escolas estratégias políticas que busquem formas de controle social, como o desmantelamento da educação pública, e para isso, é claro, é necessário transformar a classe docente na grande vilã da história.

O professor é de fato aquele que pode carregar o peso do insucesso dos seus alunos, porque ele é uma figura central no processo de ensino e aprendizagem. Quando já não se tem para onde atirar a culpa por uma sociedade desigual, esta recai sobre a educação, principalmente sobre quem influi diretamente sobre ela. Não nos esqueçamos, porém, que estes mesmos professores também fazem parte de uma imensa massa que segue por uma ideologia imposta por uma minoria que ocupa o poder (POMINI, 2005, p. 3). 
A educação, nos termos do Escola Sem Partido, deve ser neutra e apolítica, focando apenas nos conteúdos pertencentes a cada uma das disciplinas sem jamais haver participação dos professores e das professoras em relação a "opiniões" acerca de quaisquer que sejam os temas propostos nas aulas. Pois, em seu Artigo 5, inciso I, o projeto de lei afirma que, o professor ou a professora no ato de suas funções "não se aproveitará da audiência cativa dos alunos, para promover os seus próprios interesses, opiniões, concepções ou preferências ideológicas, religiosas, morais, políticas e partidárias" (BRASIL, 2016, p. 2).

O que nos sugere pensar que, se o ou a docente não deve em sala de aula discutir temas como as desigualdades socioeconômicas, socioespaciais, socio-históricas e socioculturais isso quer dizer que tais temas não devem ser estudados, aprendidos e apreendidos pelas turmas, não deve haver questionamentos sobre seus acontecimentos, não deve haver pensamento crítico sobre os mesmos, não deve haver indignação do povo diante das disparidades sociais que dicotomizam o país de forma hierárquica e ambivalente.

Nessa concepção, o projeto de lei afirma que:

É fato notório que professores e autores de materiais didáticos vêm se utilizando de suas aulas e de suas obras para tentar obter a adesão dos estudantes à determinadas correntes políticas e ideológicas para fazer com que eles adotem padrões de julgamento e de conduta moral - especialmente moral sexual - incompatíveis com os que lhes são ensinados por seus pais ou responsáveis (BRASIL, 2016, p. 4).

O que parece óbvio, como aponta Freire (2017c), consequentemente, querer dizer que para as classes hegemônicas que verdadeiramente governam o Brasil é necessário que as classes menos favorecidas permaneçam nas condições de oprimidos, tendo seus direitos violados e que não sejam capazes de pensar de forma crítica sobre tais condições, mantendo a hegemonia no poder. O povo segue como marionete nas mãos de quem precisa dele para se sustentar no poder. Só há opressão quando a manutenção do poder mantém uma parcela da população oprimida.

Desse modo, a escola precisa abrir as portas para condições que possam proporcionálas a ser um "espaço em que os sujeitos possam se significar politicamente de modo que tanto os sujeitos como os sentidos sejam não mera reprodução, mas transformação, resistência e ruptura" (ORLANDI, 2007, p. 307). É superar os obstáculos daquilo que Paulo Freire (2017b) nomeou de educação bancária, de forma a romper com a padronização e inverdades impostas e disseminadas pela estratégia politicamente arquitetada do Escola Sem Partido, não tratando 
nossos alunos e alunas como meros e meras consumidores ou consumidoras. Pois, "ensinar exige respeito aos saberes dos educandos. [...] Por que não estabelecer uma 'intimidade' entre os saberes curriculares fundamentais aos alunos e a experiência social que eles têm como indivíduos?" (FREIRE, 2017b, p. 30). Negar a realidade é isolar a escola da sociedade, é tratar a educação como mera reprodutora de - específicos e selecionados - saberes acumulados diante da história da humanidade.

Ao questionar os limites da democracia diante dos rumos tomados pelo Brasil nas últimas décadas após o golpe militar de 1964, Rubem Alves (2002) se vê diante de um dilema intrigante sobre a democracia e a educação. Diante das reflexões do autor, é possível elencarmos seu pensamento diante dessa estreita relação, pois para ele, "aqui se encontra a delicadeza e fragilidade da democracia: para que ela se realize [a democracia], é preciso que o povo saiba pensar. Se o povo não souber pensar, votos e eleições não a produzirão" (2002, p. 32, grifo meu). Logo, é necessário que haja pensamento, reflexão e diálogo na educação e não um isolamento da mesma diante da realidade em que vivemos. Assim, o autor conclui que "o fundamento da democracia é a educação do povo" (2002, p. 32). No mais, a educação precisa ser livre de amarras que possam fazê-la reducionista, opressora e discriminatória.

É importante ressaltar, ainda, que as concepções de poder e, consequentemente, de democracia que se fazem presentes nesse texto estão baseadas em concepções de Rousseau (2017) - não necessariamente sobre um conceito democrático instituído por ele, mas sim, na aplicação de suas ideias ao analisarmos o desenvolver da democracia brasileira em relação ao poder do povo -, ao contrapor Hobbes, sobre a ideia do pacto de poder e representatividade no governo. Assim, como acredita Rousseau, e concordamos, ao haver um governante que busque a representatividade do povo, isso não quer dizer, em momento algum, que há transferência do poder do povo para o representante, pois, o poder do povo continua sendo do povo. Assim, na democracia, o representante político ocupa a posição para servir ao Estado, e consequentemente, ao povo, assim como garante a Constituição Federal de 1988, em seu artigo 1, parágrafo único, "Todo o poder emana do povo, que o exerce por meio de representantes eleitos ou diretamente, nos termos desta Constituição" (BRASIL, 2016, p. 11). Porém, acreditamos ser necessária sua reflexão na prática, pois sabemos que na teoria somente o cotidiano brasileiro continuaria sempre o mesmo, como observamos ao longo da história. O poder do povo diante de seus direitos, dentro ou fora da educação, precisa ser feito na prática, e não só na teoria. 


\section{POR UMA EDUCAÇÃO AUTÔNOMA, DEMOCRÁTICA E DE DIREITO}

Uma Para uma educação que se preze democrática, é inconformável que o ou a profissional docente negue ao ou a estudante o olhar crítico, a curiosidade, a vontade incessante pela busca do novo, de refutar paradigmas, de contrapor ideologias, de enfrentar a hegemonia, visto que, um dos maiores desafios de ser professor ou professora, é a busca pela autonomia discente, efetivando de forma digna e sólida a construção do efetivo papel da cidadania. Devemos, sem dúvidas, propor a reflexão em pauta para a afirmação de que a educação não é um privilégio, assim como, a cidadania também não. É muito importante levarmos para as salas de aula que todas as nossas ações têm uma reação, e que todo direito vem acompanhado de dever. Se apenas queremos direitos, sem nos preocuparmos com os deveres, não buscamos então direitos e sim privilégios.

Em relação aos conceitos de autonomia e liberdade, que ora ou outra apareceram e ainda aparecerão nesse artigo, são baseadas na reflexão de Kant (2002) que os correlaciona na prática cotidiana em sociedade pois, para o autor, antes da autonomia vem a heteronomia. A heteronomia seria, no sentido literal, "lei alheia” e, como aponta Kant, é obedecer à lei. Só então se passa para a autonomia, que seria a lei própria. Nesse contexto, a compreensão é fácil, pois autonomia não significa viver alheio às leis sociais, mas sim admitir que as leis sociais são boas para si. Como por exemplo, a lei do cinto de segurança. Essa lei nos obriga a utilizar o cinto de segurança ao entrarmos em automóveis, seja como passageiros ou passageiras ou como motorista. Quando admitimos que é realmente mais seguro circular em automóveis utilizando o cinto, passamos da heteronomia para a autonomia. Dai expressa-se a liberdade quanto a assumir postura crítica diante das questões que protegem ou ferem a democracia, objetivando autonomia diante dos direitos e deveres de ser cidadão e cidadã.

Quanto a essas concepções no âmbito educacional, mais precisamente do direito à educação democrática, é possível compreendermos que a heteronomia conduz à educação um direito social, que deve ser garantido a todos e todas. Quando o indivíduo compreende ser de fato uma necessidade a educação como direito para afirmação de seus direitos e deveres enquanto cidadão ou cidadã, passa-se então a autonomia, entende a liberdade de compreender que a educação é e deve ser um direito garantido por um Estado democrático. Encontramos então a tão falada educação como prática para a liberdade, de Paulo Freire 
(2017a), onde a autonomia (2017b) cabe então ao processo próprio de liberdade diante da educação, que antes, precisa, necessariamente, ser entendida como um direito de todos e todas, para então ser compreendida como um direito individual da democracia.

Assim, em uma sociedade como a nossa, hierarquizada por privilégios, torna-se essencial a visão docente diante da busca por justiça social à postura de questionadores e questionadoras, a postura de quem não aceita de bom grado qualquer que seja a violência, a opressão, a discriminação. Parece utópico, e talvez seja. "Sem horizonte utópico é impossível ensinar" (CANDAU, 2002, p. 35). Mas devemos manter a ciência de que há tempos já sabemos que a educação não é capaz, sozinha, de mudar a sociedade e que, muito menos, é capaz de apagar o passado. Todavia, usemos da memória como ato de resistência. Não devemos, nunca, esquecer o que se passou, até porque, as consequências desses eventos estão enraizadas em nosso tecido social. Não devemos esquecer nosso passado escravocrata, nem o golpe militar de 1964. Não devemos porque o racismo continua presente em nossa sociedade, e o conservadorismo político toma conta do nosso país. Como aponta Viola (2010, p. 22) “a memória nacional frequentemente esquece-se de si mesma, ocultando o extermínio dos povos indígenas, a brutalidade da escravidão, a repressão sem limite contra os que reagiram ao colonialismo, as desigualdades da monarquia e as promessas não cumpridas da república".

Não devemos jamais esquecer o dia de ontem, por mais dolorido que seja, pois da dor seguiremos em pé diante das lutas nas quais precisamos combater diariamente. As mulheres ainda precisam lutar por seus direitos, as pessoas não-cis-heterossexuais 5ainda precisam combater a violência para sobreviver, os e as negros e negras ainda precisam lutar para se afirmar em sociedade, a população indígena ainda precisa lutar por suas terras, ainda é preciso combater a marginalização. E se a educação não é capaz de proporcionar tal mudança sozinha, ela é, sem sombra de dúvidas, a ferramenta principal de mobilidade social que nos proporciona o arcabouço da luta e da resistência.

Ainda hoje, a democracia brasileira se vê em patamares dicotômicos entre a realidade e os textos constitucionais. Apesar de avanços, encontramo-nos em um período sombrio que rege o temor de retrocedermos a patamares já conhecidos por nós, brasileiros e brasileiras, ou que deveriam ser conhecidos. Na história e historiografia nacionais, percursos incrédulos

\footnotetext{
${ }^{5} \mathrm{O}$ termo refere-se a qualquer pessoa que esteja fora do padrão cis-heterossexual, como os gays, lésbicas, transgêneros, bissexuais, intersexuais, dentre outros que são representados pela sigla LGBTQIA+.
} 
se fazem reais diante de ações de desgovernos que afetaram e ainda afetam a vida de um contingente massivo de indivíduos aos quais a sobrevivência é um ato político. Sobreviver o espaço social, para muitos, é sobreviver às injurias e injustiças diárias. É ter medo de sair de casa, é não saber se voltará.

Para que a democracia se mantenha como forma instituída de organização social e política se torna indispensável que seus cidadãos, como sujeitos de direitos, desempenhem ações significativas na gestão das políticas públicas. Ao contrário, se sua forma de pensar e agir estiverem controladas, ou suas informações e escolhas forem restringidas, a cidadania não desempenhará papel significativo e a democracia e os direitos humanos ameaçados (VIOLA, 2010, p. 21).

Por meio da educação, partindo de pressupostos autônomos e democráticos, podemos (re)construir caminhos que dialoguem com a incorporação de direitos na prática cotidiana da sociedade. Aguçar a crítica, aprimorar a sensibilidade, pensarmos no amor, na solidariedade, na perspectiva de um lugar melhor para viver, pois, como aponta Carbonari (2010, p. 109) "querer isso pode parecer utópico. Que seja, no sentido de que estará se construindo um lugar novo ao qual se pretende chegar, cada dia um pouco, e "descansar"!". Descansar no sentido de resistir, de estarmos aptos a convivermos com dias melhores, em uma sociedade menos desigual, menos injusta.

Desse modo, a educação nos permite alçar voos que fazem nossas mentes alcançarem novos horizontes, e ao mesmo tempo, que mantém nossos pés firmes ao chão. Pois, nenhuma das palavras escritas aqui se trata de sonhos inalcançáveis, mas sim, de acreditar na força que a educação tem para fazer de nós sujeitos sempre inacabados ${ }^{6}$ na busca sempre pelo aprimoramento e reconstrução. De tempo ao tempo, na realidade de cada época e de cada sociedade. Para isso, notoriamente, o pensamento se faz mais do que necessário, pois, como educadores e educadoras devemos ensinar nossos e nossas alunos e alunas a pensar, a buscar, a questionar, a refletir. Entretanto, pensar vai além de saber as respostas e se faz necessário elaborar as perguntas. Devemos aguçar a busca pelas perguntas, pelo olhar crítico, para assim, chegarmos as respostas. Sem as perguntas as respostas seriam nada mais que concretudes vazias de aspirações infundadas. Não são as respostas que transformam o mundo, são as perguntas.

\footnotetext{
${ }^{6} \mathrm{Na}$ verdade, o inacabamento do ser humano é o próprio da experiência vital. Onde há vida, há inacabamento. Mas só entre mulheres e homens o inacabamento se tornou consciente (FREIRE, 2017a, p. 49). 
O pensamento é como a águia que só alça voo nos espaços vazios do desconhecido. Pensar é voar sobre o que não se sabe. Não existe nada mais fatal para o pensamento do que o ensino das respostas certas. Para isso existem as escolas: não para ensinar as respostas, mas para ensinar as perguntas. As respostas nos permitem andar sobre a terra firme. Mas somente as perguntas nos permitem entrar pelo mar desconhecido (ALVES, 2003, p. 56).

Nessa lógica, se entender a educação for buscar a neutralidade, o "pensamento neutro", como propõe o Escola Sem Partido, podemos afirmar que a educação então não existiria, pois "para que a educação não fosse uma forma política de intervenção no mundo era indispensável que o mundo que ela se desse não fosse humano" (FREIRE, 2017b, p. 109). É impossível educar, ensinar, aprender e apreender por neutralidade. A neutralidade política nada mais é do que uma falácia inventada pela hegemonia opressora que busca a manutenção do poder diante dos oprimidos. "Lavar as mãos em face da opressão é reforçar o poder do opressor, é optar por ele" (FREIRE, 2017b, p. 109).

Para que a educação fosse neutra era preciso que não houvesse discordância nenhuma entre as pessoas com relação aos modos de vida individual e social, com relação ao estilo político a ser posto em prática, aos valores a ser encarnados. Era preciso que não houvesse, em nosso caso, por exemplo, nenhuma divergência em face da fome e da miséria no Brasil e no mundo; era necessário que toda a população nacional aceitasse mesmo que elas, miséria e fome, aqui e fora daqui, são uma fatalidade do fim do século (FREIRE, 2017b, p. 108-109).

Neutralidade política é conservadorismo, e o conservadorismo é antirrevolucionário e antidemocrático. Buscar uma educação neutra é negar a democracia, é buscar a homogeneidade biologizada de culturas e seres diferentes - não desiguais -, é negar a pluralidade conhecida e reconhecida por todos e todas. Como compreende Ferrero (1989), devemos entender as diferenças como uma vantagem pedagógica e não como um obstáculo a ser superado.

[...] uma das tarefas mais importantes da prática educativo-crítica é propiciar as condições em que os educandos em suas relações uns com os outros e todos com o professor ou a professora ensaiam a experiência profunda de assumir-se. Assumir-se como ser social e histórico, como ser pensante, comunicante, transformador, criador, realizador de sonhos, capaz de ter raiva porque é capaz de amar. Assumir-se como sujeito porque capaz de reconhecer-se como objeto. A assunção de nós mesmos não significa a exclusão dos outros. É a "outredade" do "não eu", ou do tu, que me faz assumir a radicalidade do meu eu (FREIRE, 2017b, p. 42, grifos do autor). 
Ensinar, sem dúvidas, é ato de coragem. É estar na linha de frente. É movimento e continuidade. Ensinar necessita de sonhos, mas também de realidade. A educação precisa ser fundamentada na realidade que temos, para assim superarmos os verdadeiros obstáculos que impedem nosso progresso, como o sexismo, o cissexismo, o racismo, o feminicídio, a homofobia, a lesbofobia, a bifobia, a transfobia, e tantas outras formas perversas nas quais se moldou o Brasil. Ensinar é combate, é vivência, é luta e também é solidariedade. "É por isso que transformar a experiência educativa em puro treinamento técnico é amesquinhar o que há de fundamentalmente humano no exercício educativo: o seu caráter formador" (FREIRE, 2017b, p. 34).

Logo, a educação precisa ser autônoma, democrática, laica e livre. Ela precisa proporcionar aos educandos e as educandas as concepções necessárias para viver em sociedade, usufruindo de forma digna de todos os conhecimentos historicamente acumulados. E não porque a sociedade deve agir de bondade, mas porque é um direito e um dever de todos e todas. Educar para ser, e não para ter. Ensinar para progredir, e não para retroceder. Ao caminhar, todos e todas nós temos o direito de tropeçar em obstáculos pelo caminho, e não há nada de errado nisso, pelo contrário, só saberemos ultrapassar obstáculos quando tropeçarmos neles. Entretanto, para tropeçarmos precisamos estar andando, e aqui o que buscamos é seguir em frente, sem nunca, esquecermos o passado. Viola (2010, p. 21), concordando com Bobbio, assimila que

Um Estado e uma sociedade somente sejam considerados democráticos quando se constituam sob a égide dos direitos humanos, na medida em que se tornem capazes de reconhecer e recriar direitos, reinstituindo e ressignificando permanentemente o social e o político num movimento que não recusa os conflitos existentes entre classes, entre grupos e indivíduos.

No entanto, vivemos tempos em que defender os direitos humanos, principalmente no Brasil, se tornou algo pejorativo. Foram criados artifícios para consolidar inverdades sobre os direitos humanos e a necessidade de os reafirmarmos.

Para que a democracia se consolide torna-se indispensável a vigência plena dos direitos sociais e econômicos. Sem esta garantia as promessas dos direitos humanos correm o risco de não se efetivarem, e mesmo os direitos civis e políticos passarem a sofrer ameaças, ora da corrupção do processo político, ora da, ainda presente, cultura autoritária. O ideal para a consolidação da democracia é que as diferentes gerações de direitos humanos se façam presentes solidariamente e se constituam como independentes e inter-relacionados (VIOLA, 2010, p. 21). 
Nesse patamar, é extremamente necessário, no Brasil atual, repensarmos o papel da educação e, consequentemente, da atividade docente. Apesar de, em dezembro de 2018 ter sido arquivado, o projeto lei do Escola Sem Partido veio nos proporcionar a mais que necessária reflexão crítica sobre o falso discurso da neutralidade política, da doutrinação realizada por professores e professoras e dos discursos um tanto quanto opressores que englobam as questões escolares sob a ótica do ódio as diferenças.

Pois é importante afirmar que um currículo e uma ação docente que se propõem a tensionar o mundo em que os alunos estão implicados traz a possibilidade de colocar em movimento processos de subjetivação, porém com resultados não podem ser previstos. Ao dizer-se neutra e apolítica, ela naturaliza e reforça as formas conhecidas do viver. Ao pretender ensinar apenas conteúdos neutros e úteis, rende-se a uma lógica de mercado. Portanto, uma escola que se diz neutra tem, sim, uma orientação política. Uma orientação que visa formar subjetividades capitalísticas conservadoras e voltadas para a defesa de seus próprios interesses individuais (SARAIVA \& VARGAS, 2017, p. 77).

Se a concepção de ensino pelo ou pela docente se fundamentar na mera transmissão, reduzindo a tarefa de educar à utilização de livros didáticos, de textos prontos, em cujas páginas os conteúdos estão finalizados, acabados e programados; se o professor ou a professora acredita no monólogo docente como atributo essencial na relação ensinoaprendizagem; se minimiza o conhecimento, entendendo-o como conteúdos que precisam ser memorizados, este professor ou esta professora compreende o ensino de uma forma técnico-instrumental. Essa perspectiva não enxerga no aluno ou na aluna um ser humano cidadão ou cida dã, com possibilidades discursivas e capacidade de entendimento das relações existentes no mundo.

O professor ou a professora pode, ao contrário, compromissar-se com uma educação para a emancipação. Nesse sentido, visualizará seu cotidiano a partir de uma relação dialógica, em que a troca discursiva ocorre a todo momento com a turma, principalmente em sala de aula. Compreenderá o conhecimento como processo, aquisições em construção, portanto, intrinsecamente relaciona do ao ato da descoberta, através também da ação discursiva e das interações que ocorrem no coletivo da sala de aula.

Podemos pensar, no entanto, que palavras como cidadania são utilizadas diariamente em diversas situações diferentes e que muitas vezes passam despercebidas por nós. Nos 
últimos anos, especialmente, o discurso da cidadania tem estado na ordem cotidiana e apareceu subjacente às mais diferentes propostas políticas. Há momentos até em que duvidamos da existência da tal democracia ou da dita cidadania. Então, é uma ação de responsabilidade docente a reflexão em torno da complexidade e da transformação teórica e prática do que chamamos cidadania. Para Pedro Demo (1995), cidadania é "assim, a raiz dos direitos humanos, [...] competência humana de fazer-se sujeito, para fazer história própria, coletivamente organizada" (p. 3).

\begin{abstract}
Ao reconhecer que, precisamente porque nos tornamos seres capazes de observar, de comparar, de avaliar, de escolher, de decidir, de intervir, de romper, de optar, nos fizemos seres éticos e se abriu para nós a probabilidade de transgredir a ética, jamais poderia aceitar a transgressão como um direito mas como uma possibilidade. [...] Não junto a minha voz a dos que, falando em paz, pedem aos oprimidos, aos esfarrapados do mundo, a sua resignação. Minha voz tem outra semântica, tem outra música. [...] Não posso ser professor se não percebo cada vez melhor que, por não poder ser neutra, minha prática exige de mim uma definição. Uma tomada de posição. Decisão. Ruptura (FREIRE, 2017b, p. 111-115).
\end{abstract}

Em outras palavras, cabe a todo e toda docente, pensar sobre a sociedade em que vive, sobre as contradições que o cercam, as possibilidades de dialogar sobre essas situações e buscar alternativas para, se não resolvê-las, pelo menos mitigá-las. A luta pela educação democrática, autônoma e livre pode ser pensada enquanto expressão de participação e cidadania, assim como a busca/construção de estratégias de trabalho que possam envolver os nossos e as nossas alunos e alunas com as questões para as quais estamos, muitas vezes, já pouco disponíveis, como as relativas à vida cidadã.

\title{
CONSIDERAÇÕES FINAIS
}

Notoriamente, o Escola Sem Partido não demonstra preocupação com uma educação que possa ser dita democrática, que vise a cidadania para todos e todas em termos de justiça social e igualdade. As propostas levantadas pelo projeto lei, nada mais são, do que estratégias arcabouçadas no conservadorismo político que nega o direito à educação as classes menos favorecidas da sociedade e reforça tal direito para as classes dominantes. Tais propostas visam a marginalização ainda mais severa a toda e qualquer pessoa que se vê fora dos altos padrões sociais que se estipulam em nossa sociedade, e que aprisionam linguagens, corpos, gêneros, 
sexualidades, religiões, culturas e etnias a moldes reducionistas e falseados da composição plural e multicultural do tecido social.

Na ideologia do Escola Sem Partido, a educação deve ser neutra e descompromissada de responsabilidade social. E em que realidade tal situação se aplicaria, numa realidade que não existe? A educação precisa ser autônoma, livre e laica para que a cidadania seja de fato justa e igualitária, e que assim, busque uma democracia em mesmos patamares de emancipação. Não podemos, e nem devemos assumir a educação como uma mera transmissão de conhecimentos isolados e de que nada mais servem do que para fazer nossos educandos e nossas educandas serem aprovados ou aprovadas em vestibulares e concursos públicos.

A educação deve preconizar a melhoria de vida da população, deve ser capaz de proporcionar na mesma a busca incessante por qualidade de vida, por direitos e deveres, por um país onde a violência, a opressão e a discriminação não sejam práticas diárias nas quais as pessoas sofrem todos os dias e, muitas vezes, pagam com a própria vida. Os direitos não são uma competição. Dar direito a alguém não retira o direito de ninguém. Existem direitos para todas as pessoas e estar pleno de seus direitos não significa que alguém precisa estar em posição de desigualdade. A educação precisa ser uma ferramenta de mobilização social e não uma arma de manobra social.

\section{REFERÊNCIAS}

ALVES, R. Conversas sobre Política. Campinas: Vênus, 2002.

ALVES, R. Conversas sobre Educação. Campinas: Vênus, 2003.

BALESTRERI, R. Agentes da manutenção ou construtores da transformação A Educação em Direitos Humanos e o protagonismo social dos profissionais da Segurança Pública. In: SILVA, A; TAVARES, C. (Orgs). Políticas e Fundamentos da Educação em Direitos Humanos. São Paulo: Cortez, 2010.

BRASIL. Constituição da República Federativa do Brasil. Brasília: Senado Federal, Coordenação de Edições Técnicas, 2016.

BRASIL. Lei de Diretrizes e Bases da Educação Nacional, LDB. 9394/1996.

BRASIL. Programa Escola Sem Partido. Projeto de Lei no 193/2016. 
CANDAU, V. Reinventar a escola. Petrópolis: Vozes, 2002.

CARBONARI, P. Educação Popular em Direitos Humanos: aproximações e comentários ao PNEDH. In: SILVA, A; TAVARES, C. (Orgs). Políticas e Fundamentos da Educação em Direitos Humanos. São Paulo: Cortez, 2010.

CARVALHO, C. Negação da política e politização da educação: a prática discursiva do Movimento Escola sem Partido. Revista Educação em Questão, Natal, v. 56, n. 50, p. 65-87, out./dez. 2018.

CIAVATTA, M. Resistindo aos dogmas do autoritarismo. In: FRIGOTTO, G. (Org) Escola "sem" Partido: esfinge que ameaça a educação e a sociedade brasileira. Rio de Janeiro: UERJ, LLP, 2017.

DEMO, P. Cidadania tutelada, cidadania assistida. São Paulo: Autores Associados, 1995.

FERRERO, E. Alfabetização em Processo. São Paulo: Editora Cortez, 1989.

FREIRE, P. Educação como Prática da Liberdade. São Paulo: Paz e Terra, 2017a.

FREIRE, P. Pedagogia da Autonomia. São Paulo: Paz e Terra, 2017b.

FREIRE, P. Pedagogia do Oprimido. São Paulo: Paz e Terra, 2017c.

KANT, I. Crítica da Razão Prática. São Paulo: Martins Fontes, 2002.

ORLANDI, E. Educação em Direitos Humanos: um discurso. In: SILVEIRA, R. et. al. (Orgs). Educação em Direitos Humanos: fundamentos teórico-metodológicos. João Pessoa: Editora da Universidade, 2007.

PENNA, F. O Escola sem Partido como chave de leitura do fenômeno educacional. In: FRIGOTTO, G. (Org) Escola "sem" Partido: esfinge que ameaça a educação e a sociedade brasileira. Rio de Janeiro: UERJ, LLP, 2017.

POMINI, S. Professores: heróis, vilões ou vítimas? Monografia de Licenciatura em Pedagogia. Unicamp, Campinas: 2005.

ROUSSEAU, J. Do Contrato Social. Petrópolis: Vozes de Bolso, 2017.

SARAIVA, K; VARGAS, J. Os perigos do Escola Sem Partido. Teias, v. 18, n. 51, 2017.

VIOLA, S. Políticas de Educação em Direitos Humanos. In: SILVA, A; TAVARES, C. (Orgs). Políticas e Fundamentos da Educação em Direitos Humanos. São Paulo: Cortez, 2010. 
Recebido em 14 de julho de 2020.

Aprovado em 09 de outubro de 2020

(c) $\$ 0$ 